\title{
TRANS-ENDOSCOPIC TREATMENT OF CRANIOPHARYNGIOMA AND RECOVERY FROM BLINDNESS IN ADULT PATIENT - A CASE REPORT
}

\author{
Domagoj Jugović ${ }^{1,2}$, Peter Spazzapan ${ }^{2,3}$, Andrej Porčnik ${ }^{2,3}$ and Borut Prestor ${ }^{2,3}$ \\ ${ }^{1}$ Department of Neurosurgery, Bamberg General Hospital, Bamberg, Germany; \\ ${ }^{2}$ University of Ljubljana, Faculty of Medicine, Ljubljana, Slovenia; \\ ${ }^{3}$ Department of Neurosurgery, University Medical Centre Ljubljana, Ljubljana, Slovenia
}

\begin{abstract}
SUMMARY - We report a case of trans-endoscopic transventricular approach to a large cystic craniopharyngioma. Surgery was performed three days after visual acuity on both eyes deteriorated to blindness. Magnetic resonance imaging before surgery revealed a large lesion in the suprasellar region that severely compressed the optic chiasm and displaced the third ventricle upward. The lesion was operated through the trans-endoscopic transventricular approach, with the aim of urgent decompression of the optic apparatus. At first, wide ventriculo-cysto-cisternostomy was performed, and then tumor tissue was removed. Postoperatively, visual acuity significantly improved on one eye. Our case shows that this minimally invasive technique is safe and effective and can be an alternative treatment for large cystic craniopharyngiomas. The reported case also shows that loss of vision can still be recovered even after the 72-hour period in adults.
\end{abstract}

Key words: Craniopharyngioma; Blindness; Endoscopy

\section{Introduction}

Craniopharyngiomas develop from epithelial remnants of Rathke's pouch located along the sella turcica, pituitary stalk and hypothalamus or on the floor of the third ventricle. More than half of all craniopharyngiomas are predominantly cystic and in these cases, controlling the mass effect is of utmost importance. They tend to compress the optic nerves and chiasm and can cause loss of visual acuity and/or visual field ${ }^{1,2}$. Surgery should tend to achieve maximal tumor removal while minimizing the risk of injuring the important adjacent structures. Therefore, surgical approach should be individualized for each patient. In cases of partial tumor removal, additional radiation therapy is recommended. In our case, trans-neuroendoscopic transventricular

Correspondence to: Domagoj Jugovic, Klinikum Bamberg, Buger Straße 80, 96049 Bamberg, Germany

E-mail: djugovic@yahoo.com

Received April 6, 2020, accepted August 20, 2020 approach allowed not only to immediately decompress the optic apparatus in an acute phase after complete loss of vision with a minimally invasive and low-risk procedure but also tumor resection. There are only few reports in the literature demonstrating significant improvement of vision following surgery, especially in cases of complete blindness ${ }^{3,4}$.

\section{Case Report}

A 56-year-woman presented for observation after a 3-day bilateral complete blindness. Five years before, visual field on her right eye had started to deteriorate with scotoma. Magnetic resonance imaging (MRI) at that time revealed a $1-\mathrm{cm}$ large suprasellar lesion that caused no endocrine disorders. Three years later, the cystic lesion enlarged to $2 \mathrm{~cm}$, with upward compression of the optic chiasm and causing associated bitemporal hemianopsia. Ophthalmologic examination revealed visual acuity of 0.8 on the left eye and counting fingers on the right eye. Visual evoked potentials 

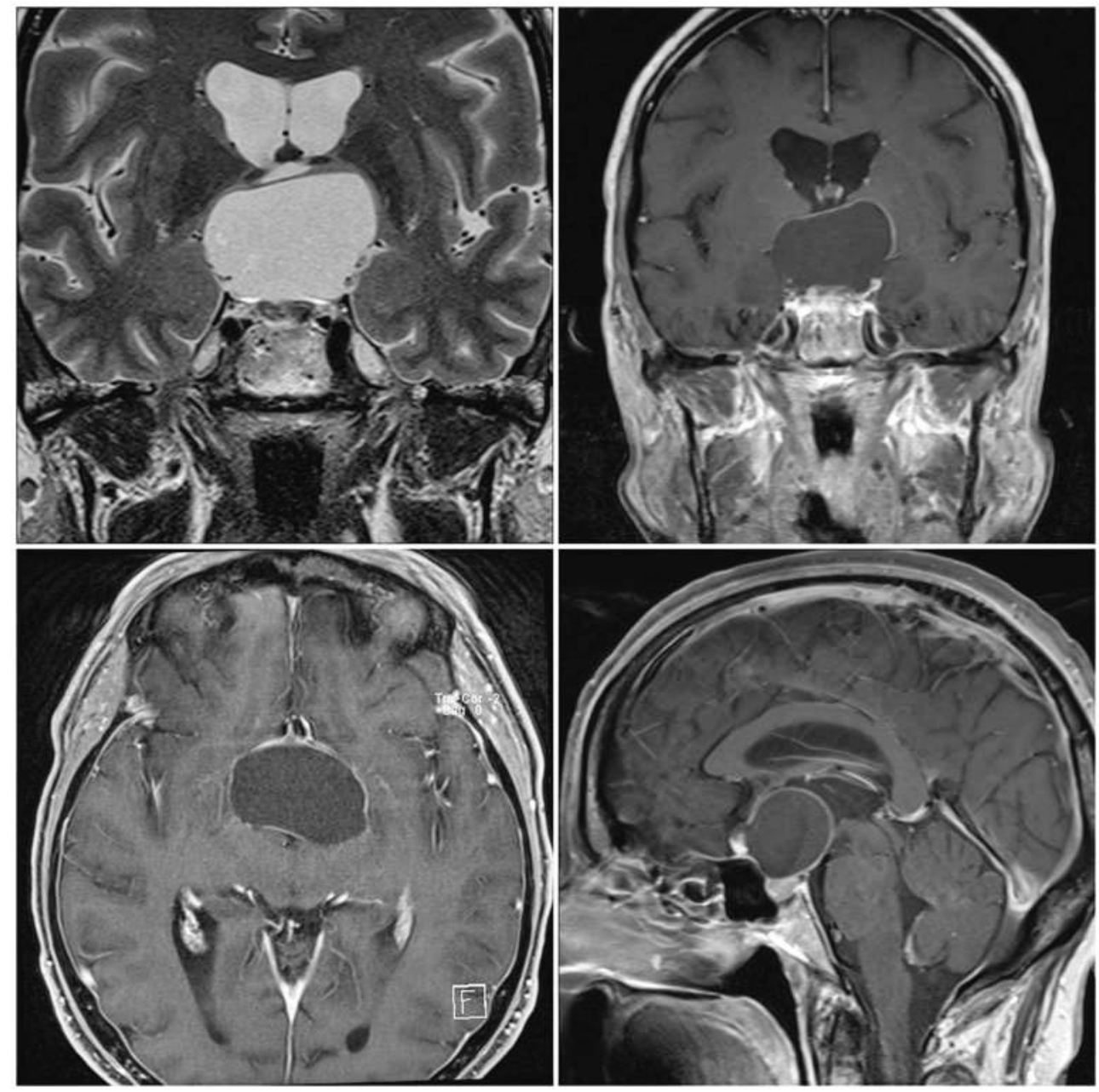

Fig. 1. Preoperative MRI scans show $3 \times 4$ cm large cystic craniopharyngioma compressing the chiasm and the $3^{\text {rd }}$ ventricle upward.

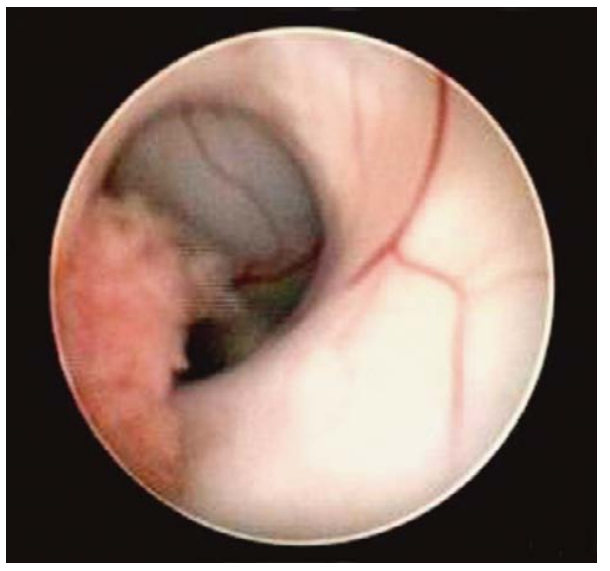

Fig. 2. The right foramen of Monro. The superior part of the cyst dome was bulging into the $3^{\text {rd }}$ ventricle.

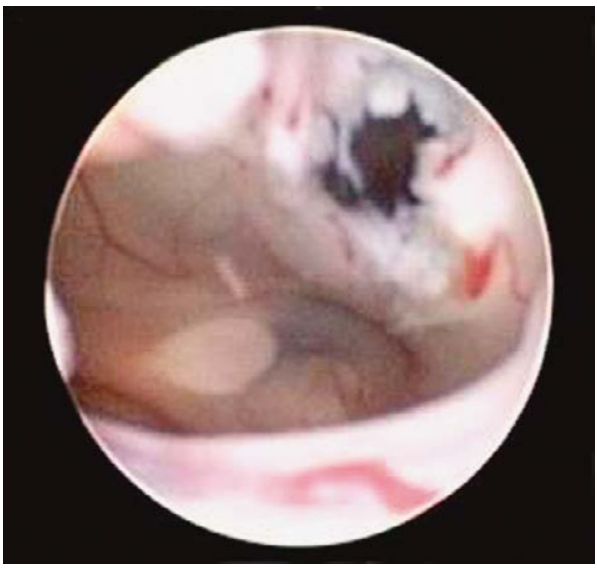

Fig. 3. Endoscopic view through the foramen of Monro. The distended anterior wall of the $3^{\text {rd }}$ ventricle together with the cyst wall was perforated in the midline. 

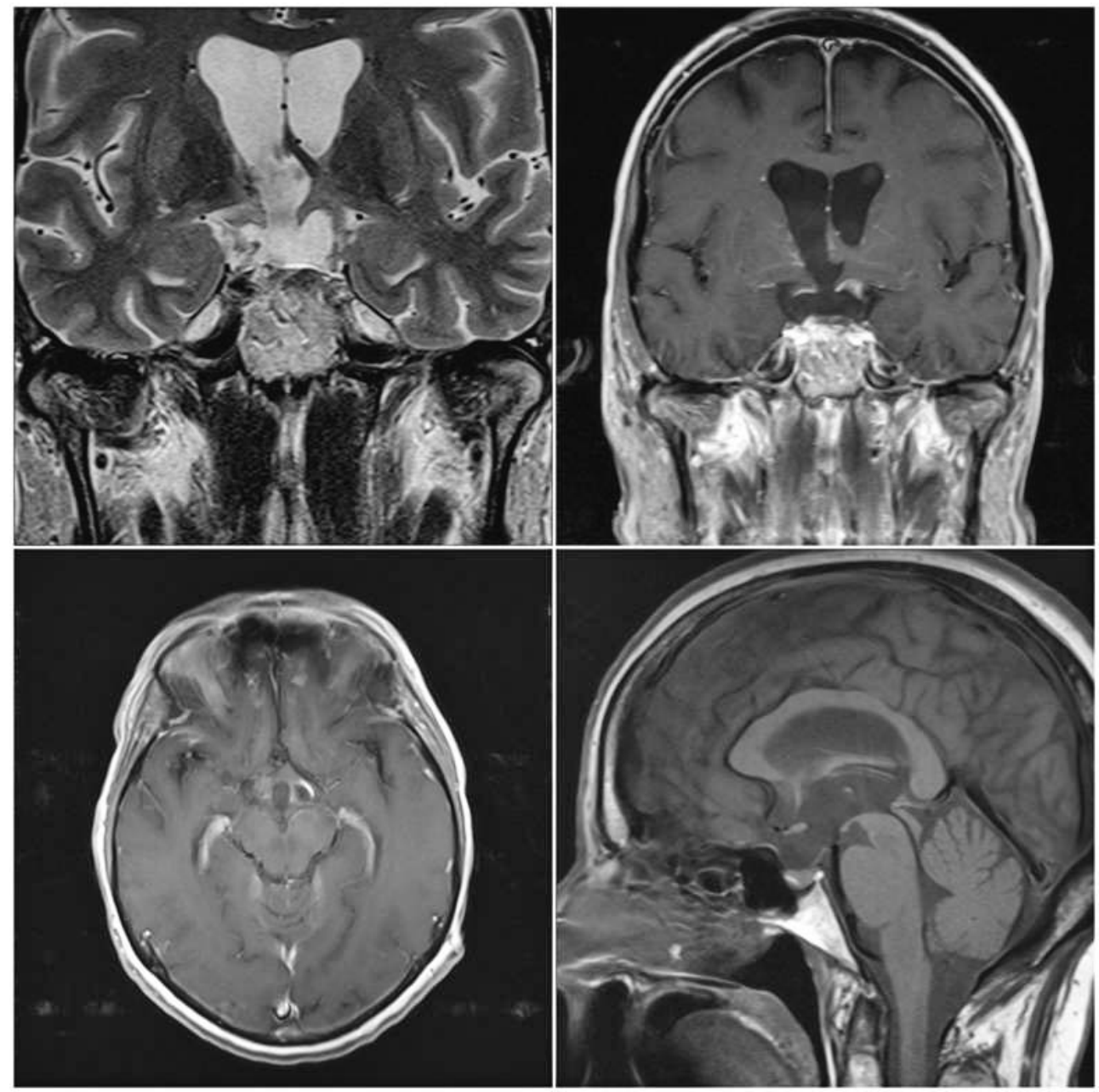

Fig. 4. MRI scans three months after the surgery show the result of ventriculo-cystocisternostomy and tumor removal. The optic apparatus is completely decompressed. Diagnostic imaging showed no visible tumor residual or hydrocephalus.

(VEP) revealed abnormal conduction due to compression of the visual pathway at the chiasm. Transcranial microsurgical removal of the cystic tumor was suggested, but the patient refused the operation. After 13 months, she developed acute blindness. Three days after this event, she was referred to the neurosurgery department. On admission, her pupils were bilaterally fixed and dilated and the optic discs were bilaterally pale. MRI demonstrated further increase of the suprasellar cystic lesion up to $3 \times 4 \mathrm{~cm}$ (Fig. 1). Only at this stage, she gave her consent for operation.

The operation was performed using a rigid endoscope with four channels, 0 - and 30-degree lenses (Aesculap AG, Tuttlingen, Germany). Neuronavigation (Medtronic) was used for trajectory planning. A small skin incision was made $2 \mathrm{~cm}$ laterally from the midline and just in front to the right coronal suture. Standard single burr hole trepanation was made and the dura was opened. The endoscope was inserted in the right lateral ventricle transcortically. The superior part of the cyst dome was bulging into the $3^{\text {rd }}$ ventricle just under the level of the foramen of Monro (Fig. 2). Therefore, the anterior wall of the $3^{\text {rd }}$ ventricle was extremely distended and thin. The endoscope was introduced through the right foramen of Monro and the distended anterior wall was perforated in the midline. Together with the ventricular wall, the cyst wall was also perforated using bipolar coagulation (Fig. 3). The cyst cavity was filled with a dense, yellowish fluid. A few millimeters large nodules and cholesterol crystals 
were located at the fundus. Wide communication toward the chiasmatic cistern was performed in order to create connection with the subarachnoid spaces. The avascular, transparent cyst capsule was in intimate relationship with the hypothalamus, optic chiasm and nerves, and both carotid arteries. Maximal resection of the capsule was achieved, but total excision of the capsule was not possible, since stripping off the membranes from all the delicate neurovascular structures in the region would have been too risky. Dissection was done by using endoscope tip and also blunt electrode as a dissector. Accordingly, endoscope holder was not used. One surgeon held the endoscope and used the whole endoscope as a dissector while another surgeon used the instruments introduced through the working channel. Solid parts of the tumor were dissected from the surrounding structures and gross totally removed with endoscopic forceps. The pull in-pull out technique was performed for maximal tumor resection. It means that larger solid parts of the tumor were grasped with the forceps and pulled out each time together with the whole endoscope (operative video available at: https://www.youtube.com/watch?v=OvWfaC6Qv OQ\&feature=youtu.be). The diameter of the working channel was too small for passing the tumor parts through it. Pituitary stalk together with portal vessels was visualized posteriorly and under the thin cyst capsule as preinfundibular craniopharyngioma ${ }^{5}$. The optic apparatus was completely decompressed and hemostasis was performed. Dural reconstruction was made and the wound was closed in layers.

Postoperative computed tomography scan showed no edema, bleeding or ischemia. The patient did not develop hydrocephalus and did not require any kind of ventricular drainage. She had no epileptic seizure postoperatively. Due to acute blindness, an emergency surgery was required and no preoperative evaluation of the endocrine function was performed. However, postoperative endocrinological testing demonstrated insufficiency of the hypothalamic-pituitary-thyroid, gonadal axis, and indirect hyperprolactinemia. Histologic examination confirmed the diagnosis of papillary craniopharyngioma. MRI taken three months after the surgery showed no visible tumor residual and no compression on the surrounding structures (Fig. 4). Visual function started to improve soon after the operation. The left pupil was reactive to light, while the right one was only reactive to indirect light. Three months after the operation, there was no improvement of visual acuity on the right eye, while on the left eye it improved to 1.0. The discs were pale (more pronounced on the right). There was inferior temporal atrophy of the left optic disc, which was confirmed by retinal nerve fiber layer thickness measured with optical coherence tomography ${ }^{6}$. An altitudinal visual field defect was present on the left eye. The right eye remained blind. Electrophysiology showed minimal recovery on the right eye and good recovery of conduction along the optic nerve on the left eye. Additional radiation therapy was not performed. Follow-up at 5 years showed no evidence for tumor or hydrocephalus.

\section{Discussion}

Craniopharyngiomas are benign, slow growing, epithelial-squamous, encapsulated tumors of variable consistency. Tight adherences to adjacent neural tissue and vessels make their excision technically difficult. Radical microsurgical removal of craniopharyngioma is the treatment of choice. The suprasellar region, in which craniopharyngiomas usually grow, is a particularly challenging operative field where surgical radicality is often associated with significant morbidity and mortality, especially when the lesion is large ${ }^{1}$. In recent studies, one group of authors compared series of suprasellar craniopharyngiomas removed endoscopically endonasally and set indications for endonasal removal as the first method of choice ${ }^{7-9}$. Small to moderate symmetric craniopharyngiomas, not extending laterally to optic nerves and carotid bifurcation can be removed endoscopically endonasally. Asymmetric and larger lesions, those that extend to different fossae or encasing vessels should be approached transcranially as the first method of choice. In large, predominantly cystic tumors, compression rather than infiltration of the surrounding neural structures is responsible for the clinical manifestations of visual field and endocrine deficits ${ }^{10}$.

In our case, a giant cystic craniopharyngioma was responsible for the acute onset of bilateral blindness. Immediate decompression of the mass effect was of primary importance. In this particular case, transventricular approach was chosen due to urgent situation and decompression as a primary goal. However, stripping was possible and this continued to very good removal. Ventriculo-cysto-cisternostomy was created first, representing an effective and fast technique to achieve decompression ${ }^{11}$. The procedure where all ma- 
nipulations are performed through working channel of the endoscope is called trans-endoscopic. Transventricular trans-endoscopic approach was minimally invasive, safe and effective in this selected case. This approach for giant cystic craniopharyngiomas has already been described in a few cases, alone or in combination with further microsurgical removal ${ }^{12-17}$. In our case, it allowed not only decompression through creation of a wide communication between liquor spaces, but also a near-total resection of the lesion. Using this method, the cyst was clearly visualized from inside and a great portion of the capsule together with all solid parts was removed.

A disadvantage of trans-endoscopic approach is a small diameter of the working channel. Large pieces of the tumor could not be removed through the endoscope. Therefore, they were grasped with endoscopic forceps and pulled out of the head together with the whole endoscope. With this technique, we were able to remove the solid parts of the tumor as well. During this procedure, we did not notice additional damage or bleeding in the brain tissue where the endoscope was repeatedly introduced, always along the same route. The enlargement of lateral ventricles and foramen of Monro facilitated tumor removal. The fact that between the $3^{\text {rd }}$ ventricle and the cyst there was a layer of brain tissue was another disadvantage of our approach. However, only a small part of anterior ventricular wall had to be removed and this part was already significantly distended.

The postoperative visual function improved on the left eye from blindness to good visual acuity. Decompression of the optic chiasm was still performed on time, which may have been responsible for restoration of the axoplasmic flow through the optic nerves ${ }^{18}$. Blindness related to compression of the optic nerves and chiasm has been reported to be reversible within 72 hours of onset in a 3-year old child ${ }^{3}$. Children may be capable of recovery after intervals of blindness that would be considered irreversible in adults. However, our case shows that in some cases, recovery of vision is possible even after a longer time in adults as well. However, the postoperative visual field examination of the left eye showed an altitudinal hemianopic field defect, which may be consistent with ischemic damage to the left optic nerve. Subjective visual acuity and visual evoked potential amplitude did not show significant improvement on the right eye. One possible explana- tion for that is that compression of the optic nerve fibers on the right side was so severe that damage was irreversible. Another explanation is postoperative onset of local vasospasm in the right optic nerve sheath, which may have led to the irreversible ischemic injury of the optic fibers.

\section{Conclusion}

Transventricular trans-endoscopic approach can be effective in selected cases of cystic craniopharyngioma that produce a large mass effect. Anatomic and surgical characteristics of the lesion must be taken in consideration, especially with regards to extension of the cystic component and clinical picture ${ }^{2}$. In our case, this approach allowed creation of a wide communication for cerebrospinal fluid circulation and also removal of the lesion. Early decompression is of primary importance to achieve clinical improvement, especially regarding visual deficits. The reported case shows that loss of vision can be recovered even after a 72-hour period in adult patients as well.

\section{References}

1. Fahlbusch R, Honegger J, Paulus W, Huk W, Buchfelder M. Surgical treatment of craniopharyngiomas: experience with 168 patients. J Neurosurg. 1999;90:237-50. doi: 10.3171/jns. 1999.90.2.0237.

2. Yaşargil MG, Curcic M, Kis M, Siegenthaler G, Teddy PJ, Roth P.Total removal of craniopharyngiomas. Approaches and long-term results in 144 patients. J Neurosurg. 1990;73:3-11. doi: 10.3171/jns.1990.73.1.0003.

3. al-Wahhabi B, Choudhury AR, al-Moutaery KR, Aabed M, Faqeeh A. Giant craniopharyngioma with blindness reversed by surgery. Childs Nerv Syst. 1993;9:292-4. doi: 10.1007/ bf00306278.

4. Shibata T, Tanikawa M, Sakata T, Mase M. Urgent optic nerve decompression via an endoscopic endonasal transsphenoidal approach for craniopharyngioma in a 12-month-old infant: a case report. Pediatr Neurosurg. 2018;53:182-7. doi: 10.1159/ 000487086.

5. Kassam AB, Gardner PA, Snyderman CH, Carrau RL, Mintz AH, Prevedello DM. Expanded endonasal approach, a fully endoscopic transnasal approach for the resection of midline suprasellar craniopharyngiomas: a new classification based on the infundibulum. J Neurosurg. 2008;108(4):715-28. doi: 10.3171/ JNS/2008/108/4/0715.

6. Bialer OY, Goldenberg-Cohen N, Toledano H, Snir M, Michowiz S. Retinal NFL thinning on OCT correlates with vi- 
sual field loss in pediatric craniopharyngioma. Can J Ophthalmol. 2013;48:494-9. doi: 10.1016/j.jcjo.2013.05.001.

7. Bosnjak R, Benedicic M, Vittori A. Early outcome in endoscopic extended endonasal approach for removal of supradiaphragmatic craniopharyngiomas: a case series and a comprehensive review. Radiol Oncol.2013;47(3):266-79. doi: 10.2478/ raon-2013-0036.

8. Jensterle M, Jazbinsek S, Bosnjak R, Popovic M, Zaletel LZ, Vesnaver TV, Kotnik BF, Kotnik P. Advances in the management of craniopharyngioma in children and adults. Radiol Oncol. 2019;53(4):388-96. doi: 10.2478/raon-2019-0036.

9. Jazbinšek S, Kolenc D, Bošnjak R, Faganel Kotnik B, Zadravec Zaletel L, Jenko Bizjan B, Vipotnik Vesnaver T, Battelino T, Janež A, Jensterle M, Kotnik P. Prevalence of endocrine and metabolic comorbidities in a national cohort of patients with craniopharyngioma. Horm Res Paediatr. 2020;93(1):46-57. doi: 10.1159/000507702.

10. Chen C, Okera S, Davies PE, Selva D, Crompton JL. Craniopharyngioma: a review of long-term visual outcome. Clin Exp Ophthalmol. 2003;31:220-8. doi: 10.1046/j.1442-9071.2003. 00648.x.

11. Koršič M, Jugović D, Porčnik A. Endoscopic treatment of in utero diagnosed multiloculated interhemispheric cyst in a newborn: case report. Acta Clin Croat. 2013;52(1):119-24.

12. Abdullah J, Caemaert J. Endoscopic management of craniopharyngiomas: a review of 3 cases. Minim Invasive Neurosurg. 1995;38:79-84. doi: 10.1055/s-2008-1053462.
13. Cinalli G, Spennato P, Cianciulli E, Fiorillo A, Di Maio S, Maggi $G$. The role of transventricular neuroendoscopy in the management of craniopharyngiomas: three patient reports and review of the literature. J Pediatr Endocrinol Metab. 2006;19 Suppl 1:341-54.

14. Delitala A, Brunori A, Chiappetta F. Purely neuroendoscopic transventricular management of cystic craniopharyngiomas. Childs Nerv Syst. 2004;20:858-62. doi: 10.1007/s00381-0040943-1.

15. Gangemi M, Seneca V, Mariniello G, Colella G, Magro F. Combined endoscopic and microsurgical removal of a giant cystic craniopharyngioma in a six-year-old boy. Clin Neurol Neurosurg. 2009;111:472-6. doi: 10.1016/j.clineuro.2009.01.002.

16. Nakahara Y, Koga H, Maeda K, Takagi M, Tabuchi K. Neuroendoscopic transventricular surgery for suprasellar cystic mass lesions such as cystic craniopharyngioma and Rathke cleft cyst. Neurol Med Chir. 2004;44:408-13. doi: 10.2176/nmc.44.408.

17. Moore RJ, Scherer A, Fulkerson DH. Frontal burr hole approach for neuroendoscopic resection of craniopharyngioma with the NICO Myriad device: report of two cases. Childs Nerv Syst. 2017;33(4):659-64. doi: 10.1007/s00381-017-3386-1.

18. Moon CH, Hwang SC, Ohn YH, Park TK. The time course of visual field recovery and changes of retinal ganglion cells after optic chiasmal decompression. Invest Ophthalmol Vis Sci. 2011;52:7966-73. doi: 10.1167/iovs.11-7450.

Sažetak

\title{
TRANS-ENDOSKOPSKA OPERACIJA KRANIOFARINGEOMA I OPORAVAK VIDA NAKON SLJEPOĆE U ODRASLE BOLESNICE - PRIKAZ SLUČAJA
}

\author{
D. Jugovic, P. Spazzapan, A. Porčnik i B. Prestor
}

U radu je prikazana trans-endoskopska operacija velikog cističnog kraniofaringeoma transventrikulskim pristupom. Bolesnica je operirana tri dana nakon što je potpuno oslijepila. Magnetska rezonanca prije operacije je pokazala veliku cističnu leziju u supraselarnoj regiji s izrazitom kompresijom optičke kijazme i treće moždane komore. Učinjena je trans-endoskopska operacija transventrikulskim pristupom s ciljem hitne dekompresije optičkog aparata. Najprije je šupljina ciste povezana sa subarahnoidnim prostorom i trećom moždanom komorom, a nakon toga je odstranjen solidni dio tumora. Nakon zahvata se vid na jednom oku značajno popravio. Ovaj slučaj pokazuje da trans-endoskopska, minimalno invazivna transventrikulska operacija može biti sigurna i učinkovita metoda u liječenju velikih cističnih kraniofaringeoma. Također pokazuje da je oporavak vida u nekim slučajevima moguć i nakon 72 sata potpune sljepoće u odraslog bolesnika.

Ključne riječi: Kraniofaringeom; Sljepoća; Endoskopija 